\title{
Religious Discrimination among Muslim Employees Diskriminasi Agama Dalam Kalangan Pekerja Muslim
}

\author{
Muhammad Farhan Hazaha a*, Rabeatul Husna Abdull Rahman ${ }^{\mathrm{a}^{*},}$ Nurul Labanihuda Abdul Rahman ${ }^{\mathrm{b}}$ \\ ${ }^{a}$ Faculty of Social Sciences and Humanities, Universiti Teknologi Malaysia, 81310 UTM Johor Bahru, Johor, Malaysia \\ ${ }^{b}$ Faculty of Business and Management, Universiti Teknologi Mara, 02600 UiTM Perlis, Malaysia
}

*Corresponding author: rabeatulhusna@utm.my

Article history: Received 10 April 2020 Received in revised form: 30 June 2020 Accepted: 01 July 2020 Published online: 31 August 2020

\begin{abstract}
This study aims to examine religious discrimination against Muslim workers. There are three objectives in this study, namely to identify the level of discrimination against Islam, to identify differences in the level of discrimination against Islam between the sexes, and to identify differences in the level of discrimination against Islam between employers of different religions. Purposive sampling and snowball sampling methods were used to select a sample consisting of Muslim workers working as salesmen. A total of 132 questionnaires were analyzed from four different shopping complexes in Johor Bahru, Johor. The results of the study found that the level of religious discrimination is at a low level. In addition, researchers also found that male workers were more likely to experience religious discrimination than female workers. In terms of the religion of employers, non-Muslim employers are more likely to discriminate against religion than Muslim employers. In conclusion, in the context of this study, religious discrimination against Muslim workers is at a low level.
\end{abstract}

Keyword: Discrimination, Religious Discrimination, Islam

\begin{abstract}
Abstrak
Kajian ini bertujuan untuk mengkaji diskriminasi agama terhadap pekerja Islam. Terdapat tiga objektif yang dikaji dalam kajian ini iaitu mengenalpasti tahap diskriminasi terhadap agama Islam, mengenalpasti perbezaan tahap diskriminasi terhadap agama Islam antara jantina, dan mengenalpasti perbezaan tahap diskriminasi terhadap agama Islam majikan yang berlainan agama. Kaedah pensampelan bertujuan dan pensampelan bola salji digunakan untuk memilih sampel yang terdiri daripada pekerja beragama Islam yang bekerja sebagai jurujual. Sebanyak 132 soal selidik telah dianalisa daripada empat buah kompleks membeli belah berbeza di Johor Bahru, Johor. Hasil dapatan kajian mendapati bahawa tahap diskriminasi agama berada pada tahap rendah. Selain itu, pengkaji turut mendapati bahawa pekerja lelaki lebih cenderung untuk mengalami diskriminasi agama berbanding pekerja wanita. Dari segi agama majikan pula, majikan bukan beragama Islam lebih cenderung untuk melakukan diskriminasi agama berbanding majikan beragama Islam. Sebagai kesimpulan, diskriminasi agama terhadap pekerja Islam di tempat kajian yang telah dinyatakan oleh pengkaji berada pada tahap rendah.
\end{abstract}

Kata kunci: Diskriminasi, Diskriminasi Agama, Agama Islam

(C) 2020 Penerbit UTM Press. All rights reserved

\subsection{PENGENALAN}

Istilah diskriminasi secara umumnya merujuk kepada tingkah laku positif atau negatif terhadap kumpulan sosial dan ahli-ahlinya (Smith dan Mackie, 2002), manakala diskriminasi agama merujuk kepada layanan tidak baik terhadap seseorang pekerja kerana kepercayaan agamanya (Equal Employment Opportunity Commission, 2008). Menurut William et al, (2012) diskriminasi boleh terjadi dalam pelbagai bentuk dan disebabkan pelbagai faktor yang berbeza. Ia boleh terjadi kepada sesiapa sahaja tanpa mengira kaum, bangsa dan agama.

Di Malaysia, diskriminasi terhadap pekerja beragama Islam masih terjadi walaupun Malaysia merupakan sebuah negara majoriti Muslim. Dalam kajian oleh Rafidah Hanim (2018), beliau mendapati bahawa tahap diskriminasi agama di Malaysia berada di paras yang agak membimbangkan. Antara contoh diskriminasi agama yang pernah dilaporkan ialah larangan memakai tudung di tempat kerja oleh majikan (Rafidah Hanim et.al, 2017). Manakala, berdasarkan laporan Norhawa Mohd Ali, (2018), hasil siasatan yang dibuat oleh Kementerian Sumber Manusia pada November 2017 mendapati bahawa 13 hotel daripada 74 buah hotel bertaraf empat dan lima bintang di Pahang (33), Selangor (14), Johor (15), Kuala Lumpur (6) dan Putrajaya (6) mengamalkan polisi larangan bertudung sewaktu bekerja terhadap pekerja mereka. Selain tu, menurut Tasnim dan Atikah, (2018) terdapat pekerja beragama Islam yang ditegur oleh majikan kerana mengerjakan solat, malah sering diganggu apabila hendak mendirikan solat. Ini secara tidak langsung menunjukkan kewujudan diskriminasi terhadap pekerja beragama Islam di Malaysia yang bertentangan dengan Perkara 8 (2) Perlembagaan Persekutuan. 
Masalah ini dilihat sebagai satu perkara yang membimbangkan kerana ia boleh mengganggu emosi, psikologi, mental dan juga perpaduan masyarakat Islam di Malaysia. Contohnya, dalam kajian yang dibuat oleh Jang, Chiriboga, dan Small, (2008) didapati bahawa diskriminasi memberi kesan negatif terhadap kesejahteraan psikologi terutama sekali kepada individu yang tidak pernah mengalami sebarang diskriminasi sebelum ini. Diskriminasi juga boleh memberi kesan kepada prestasi kerja dan kepuasan kerja seseorang individu. Dalam erti kata lain individu yang mengalami diskriminasi akan berhadapan dengan kesukaran untuk melakukan tugasan dengan cemerlang (Gabbidon et al, 2014). Selain itu, diskriminasi turut memberi implikasi kepada prestasi pekerja dan produktiviti pekerja dalam organisasi (Tesfaye, 2010). Malahan, amalan diskriminasi yang dilakukan oleh majikan atau organisasi boleh mengundang rasa tidak puas hati pekerja dan mengugat keharmonian di tempat kerja (Tesfaye, 2010).

Kebanyakan majikan di Malaysia, khususnya majikan bukan Muslim yang melakukan diskriminasi terhadap pekerja Muslim mendakwa tidak mengetahui polisi yang dibuat oleh syarikat merupakan satu bentuk diskriminasi agama (Farhanah Abd. Malek, 2017). Sebagai contoh, larangan memakai tudung serta larangan mengerjakan solat. Mereka menganggap itu merupakan hak mutlak majikan untuk memastikan produktiviti syarikat mereka tidak terjejas. Berdasarkan laporan Farhanah Abd. Malek (2017) Presiden Persatuan Hotel Malaysia (MAH) mendakwa polisi larangan memakai tudung adalah sebahagian daripada polisi antarabangsa dan menjelaskan ia bukan satu bentuk diskriminasi terhadap wanita bertudung. Ini menunjukkan bahawa majikan tidak menyedari bahawa tindakan yang dibuat sebenarnya merupakan salah satu bentuk diskriminasi agama dan merupakan satu kesalahan. Di Malaysia, terdapat peruntukan undangundang berkaitan dengan diskriminasi dalam pekerjaan seperti Akta Kerja 1955 (Akta 265) dan Akta Perhubungan Perusahaan 1967 (Akta 177), yang memberi perlindungan kepada pekerja yang mengalami diskriminasi di tempat kerja (Atirah Hasli, 2017).

Di samping itu, kajian mengenai diskriminasi terhadap pekerja beragama Islam di Malaysia juga adalah terhad dan membataskan pemahaman umum mengenai diskriminasi agama di tempat kerja (Ghumman, Ryan, Barclay dan Markel, 2013). Setakat pencarian pengkaji hanya terdapat tidak lebih 20 kajian empirikal yang mengkaji tentang diskriminasi agama di Malaysia sekitar tahun 1998 hingga 2018. Contohnya kajian oleh Rafidah Hanim et al (2017), Panahi (2017), Rahmah, Zulkifly, Syazwani (2013) dan Schafgans (1998). Namun demikian, kajian-kajian ini memfokus kepada diskriminasi agama terhadap pekerja wanita Islam sahaja dan tidak memfokuskan diskriminasi terhadap pekerja lelaki Islam. Memandangkan kurang kajian mengenai diskriminasi agama secara umumnya, maka kajian ini dilakukan untuk menyiasat sejauhmana pekerja beragama Islam khususnya yang bekerja di pasaraya mengalami diskriminasi yang berkaitan dengan agama.

Secara khususnya, kajian ini dijalankan untuk (i) mengenalpasti tahap diskriminasi agama, (ii) mengenalpasti perbezaan tahap diskriminasi agama di antara jantina, dan (iii) mengenalpasti perbezaan tahap diskriminasi agama di antara majikan yang berlainan agama.

\subsection{KAJIAN LITERATUR}

Diskriminasi dalam pekerjaan merupakan suatu ancaman yang boleh terjadi kepada mana-mana pekerja, dan dalam semua sektor pekerjaan di seluruh dunia samada secara sedar atau tidak, secara langsung atau tidak (Nienartowicz, 2014). Ia juga boleh terjadi dalam pelbagai bentuk (Jones, et al, 2017). Antara contoh diskriminasi dalam pekerjaan ialah diskriminasi upah, pembuatan keputusan, peluang pekerjaan, dan juga penghinaan terhadap identiti yang dimiliki oleh individua atau kumpulan tertentu (Cheung, et al, 2016). Selain itu, bentuk diskriminasi juga boleh dikelaskan kepada beberapa kategori seperti diskriminasi agama dan jantina. Diskriminasi agama merujuk kepada perlakuan tidak sama rata terhadap individu tertentu berdasarkan agama yang dianuti (Coglievina, Hutchinson \& Van Emden, 2007). Di Malaysia, diskriminasi agama lazimnya terjadi semasa proses pengambilan pekerja di mana pihak majikan mempunyai kecenderungan untuk memilih calon yang mempunyai latar belakang agama yang sama (Panahi, 2017). Manakala, diskriminasi jantina pula lebih terarah kepada pekerja wanita berbanding pekerja lelaki. Walaupun penyertaan wanita di dalam tenaga kerja Malaysia semakin meningkat dalam pelbagai sektor seperti pembuatan, perniagaan, perkhidmatan, pertanian (Zaiton \& Nooraini, 2015), namun pekerja wanita didapati memperoleh upah yang lebih rendah berbanding pekerja lelaki (Aizat Othman, 2012). Di samping diskriminasi upah, pekerja wanita di Malaysia turut berhadapan dengan pelbagai bentuk diskriminasi yang lain seperti pembahagian pekerjaan mengikut jantina, gangguan seksual di tempat kerja, pemberhentian dan pemecatan, pengurangan faedah-faedah sampingan seperti insuran kesihatan yang terhad (Simun \& Azizan, 2016).

Menurut Parkins, Fishbein, Ritchey, (2006) diskriminasi di tempat kerja tercetus akibat prasangka peribadi atau stereotaip mengenai ahli-ahli dalam organisasi. Misalnya, stereotaip yang mengatakan agama Islam mengongkong dan mendiskriminasi wanita Islam dengan memaksa memakai tudung memperlihatkan Islam merupakan agama yang mundur dan kebelakang (Janson, 2011). Malah menurut kajian Valfort, (2015) hampir kesemua daripada responden yang ditemubual menyatakan Islam merupakan agama ekstremisme, tidak bertoleransi dan fanatik. Hakikatnya, sebarang bentuk diskriminasi adalah suatu kesalahan dan boleh menyalahi undang-undang (King \& Cotina, 2010). Ini kerana setiap pekerja di organisasi sewajarnya mempunyak hak dan peluang yang sama rata, dan perlu dilayan secara adil dan saksama, namun menurut Turner (2014), kesaksamaan hanya akan boleh dicapai dengan mengubah andaian dan struktur yang membawa kepada amalan diskriminasi di tempat kerja. Sememangnya diskriminasi di tempat kerja amat perlu ditangani, namun ia melibatkan kos yang tinggi termasuklah faktor masa, dan imej organisasi (McMahon \& Shaw, 2005).

Diskriminasi boleh mendatangkan pelbagai kesan kepada individu yang didiskrimasi seperti kesan terhadap kesihatan fizikal, mental, prestasi kerja, dan suasana tempat kerja. Sebagai contoh, kajian oleh Pavalko et al (2003) membuktikan bahawa pekerja yang mengalami diskriminasi di tempat kerja seperti dipecat akan mengalami tekanan psikologi. Dapatan kajian ini turut disokong oleh Kwaku et al, (2013), dan Gabiddon et al (2014) yang menyatakan bahawa mangsa diskriminasi, gangguan seksual, buli, dan keganasan fizikal akan mengalami masalah kesihatan mental. Di samping itu, diskriminasi juga boleh menyebabkan gangguan kesihatan fizikal sehingga boleh menjejaskan produktiviti pekerja yang mengalami diskrminasi tersebut (William, et al, 2012). Dalam erti kata lain, pekerja yang didiskriminasi tidak akan dapat menunjukkan prestasi kerja yang baik di tempat kerja (Kwaku et al, 2013), malah kualiti ouput yang dihasilkan juga adalah rendah (Isaiah et al, 2017). Implikasi diskriminasi juga tidak terhad kepada kesan individu, sebaliknya turut boleh mempengaruhi suasana di tempat kerja. Pesekitaran kerja yang tidak aman, tidak sihat, dan tidak harmoni boleh menimbulkan permusuhan akibat diskriminasi (Kwaku et al, 2013), peminggiran sosial kepada mangsa (Gabiddon et al, 2014), mendorong kepada tekanan, menghalang peluang, dan menjejaskan hubungan interpersonal di antara pekerja dan majikan (Marafuga et al, 2017). 
Perbincangan selanjutnya adalah berkaitan diskriminasi terhadap agama Islam yang menjadi fokus dalam kajian ini. Diskriminasi terhadap agama Islam semakin meruncing apabila berlakunya tragedi 11 September 2001 di Amerika Syarikat yang dilakukan oleh pejuang radikal Islam ke atas bangunan Pusat Perdagangan Dunia yang mengorbankan kira-kira, 996 orang terbunuh dan lebih daripada 6,000 yang lain cedera. Menurut Rabasa et al, (2004) tragedi 11 September 2001 telah mengubah secara dramatik persekitaran politik di dunia Islam yang terdiri daripada kumpulan negara-negara dengan penduduk Islam yang ramai dari Afrika Barat ke selatan Filipina, serta masyarakat Islam di seluruh dunia. Kesan daripada ini, umat Islam di barat khususnya di negara Amerika Syarikat mula menjadi mangsa diskriminasi agama dengan wujudnya istilah baru iaitu Islamofobia. Contohnya, pengurangan jumlah upah berbanding pekerja bukan Islam (Kaushal, Kaestner dan Reimers, 2007).

Di Perancis misalnya, masyarakat Islam terpaksa berhadapan dengan diskriminasi berbentuk undang-undang yang mengharamkan pemakaian yang melitupi muka dan badan (niqab dan burqa) di sekolah, hospital dan pengangkutan awam (Janson, 2011). Bukan itu sahaja, malah menurut Valfort (2015) calon pekerja beragama Islam yang memohon pekerjaan kurang mendapat panggilan temuduga berbanding calon pekerja beragama Katolik atau Yahudi. Di Malaysia pula, penganut agama Islam di negara ini terpaksa berhadapan dengan diskriminasi secara tidak langsung. Berdasarkan perangkaan Banci Penduduk dan Perumahan, (2000) komposisi agama rakyat Malaysia kira-kira 60.4\% menganut agama Islam, 19.2\% Buddha, 9.1\% Kristian, 6.3\% Hindu dan 2.6\% yang lain mengamalkan Konfusianisme, Taoisme dan agama Cina tradisional yang lain. Selebihnya dikira menganut kepercayaan animisme, agama rakyat, dan Sikhisme. Manakala $0.9 \%$ tidak mempunyai kepercayaan agama atau tidak memberikan maklumat.

Walaupun Malaysia merupakan negara majoriti Islam, diskriminasi terhadap pekerja Islam turut berlaku. Sebagai contoh, Rafidah Hanim et al, (2017) di dalam kajiannya mendapati pekerja Islam di Malaysia terpaksa berhadapan dengan diskriminasi seperti dilarang mengenakan tudung, tidak diberikan masa yang cukup untuk solat dan dinafikan kenaikan pangkat. Selain itu, menurut kajian Panahi, (2017) diskriminasi agama lazimnya berlaku dalam proses pengambilan pekerja, di mana pengurus bukan Islam lebih cenderung untuk mengambil pekerja yang bukan beragama Islam. Menariknya, kajian beliau turut mendapati bahawa pengurus beragama Islam juga turut cenderung untuk mengambil pekerja yang beragama Islam. Berdasarkan model diskriminasi oleh Jasperse et al (2012), masyarakat Islam mempunyai potensi untuk menjadi mangsa diskriminasi disebabkan oleh tiga faktor iaitu (i) psikologi identiti Islam, (ii) tingkah laku identiti Islam, dan (iii) identiti Islam yang ketara.

Selain agama Islam, kajian lepas turut membincangkan diskriminasi terhadap individu beragama Sikh dan Kristian. Peristiwa 11 September 2001 bukan hanya memberi impak kepada masyarakat beragama Islam, tetapi juga kepada golongan Sikh disebabkan kekeliruan masyarakat barat terhadap pemakaian turban dan juga penampilan berjanggut (Goodstein \& Lewin, 2001; Ahluwalia \& Pellettiere, 2010). Malah, berdasarkan kajian Narasaki (2007) masyarakat Sikh yang bekerja di dalam New York Police Department dikehendaki menanggalkan turban sebelum dibenarkan menyertai pasukan polis, dan sekiranya enggan, boleh dipecat daripada pekerjaan. Perkara ini adalah berbeza di Malaysia yang menghormati amalan keagamaan masyarakat Sikh yang memakai turban. Mereka tidak perlu menanggalkan turban sekiranya ingin menyertai pasukan polis, malah turut diberi pengecualian daripada memakai topi keledar sewaktu menunggang motorsikal (Shahrul \& Afiqah, 2017). Manakala di India pula, masyarakat beragama Kristian yang mengalami diskrminasi khususnya daripada segelintir pihak radikal Hindu, dan ini boleh dibuktikan dengan peningkatan kadar serangan keganasan terhadap masyarakat Kristian di India terutamanya pada tahun 2008, 2009, dan 2015 (Mays, 2017).

Konklusinya, diskriminasi dalam pekerjaan boleh berlaku dalam pelbagai bentuk, tanpa mengira agama ataupun jantina. Ia berlaku rentas sempadan, dan khusus bagi diskriminasi agama, ia juga boleh berlaku di negara yang majoritinya beragama Islam seperti di Malaysia. Tidak kira apa bentuk diskriminasi, ia tetap mendatangkan kesan yang negatif kepada mangsa, samada kesan peribadi mahupun kesan tidak langsung kepada organisasi seperti dalam bentuk penurunan prestasi dan produktiviti kerja.

\subsection{METODOLOGI KAJIAN}

Kajian ini merupakan sebuah kajian kuantitatif yang dijalankan pada tahun 2019 dan telah melibatkan seramai 132 orang responden yang terdiri daripada pekerja yang beragama Islam di empat buah kompleks membeli belah di Johor Bahru. Negeri selatan Malaysia dipilih kerana setakat pengetahuan pengkaji, kajian seumpama ini belum pernah lagi dijalankan di negeri Johor. Oleh itu, pemilihan negeri Johor sebagai lokasi kajian akan dapat menyumbang kepada kajian literatur dan pengkaji akan datang dapat membuat perbandingan diskriminasi di antara negeri-negeri di Malaysia.

Responden kajin ini telah dipilih dengan menggunakan kaedah persampelan bertujuan dan persampelan bola salji. Instrumen kajian yang digunakan ialah set soal selidik yang mengandungi tiga bahagian iaitu bahagian A: demografi, bahagian B: amalan sebagai muslim di tempat kerja, dan bahagian C: bentuk diskriminasi terhadap pekerja Islam di tempat kerja. Kedua-dua bahagian B dan C telah diadaptasi daripada Marieke Lyniska Jasperse, (2009). Terdapat 8 item bagi bahagian B, antaranya ialah 'Majikan saya membenarkan saya mengerjakan solat fardhu di tempat kerja', 'Majikan saya membenarkan saya berpuasa pada bulan Ramadhan', dan 'Majikan saya membenarkan pekerja lelaki menunaikan solat Jumaat di masjid.

Manakala bahagian C pula terdiri daripada 17 item, antaranya ialah 'Majikan saya cenderung mengambil pekerja bukan Islam berbanding pekerja Islam', 'Kerana saya beragama Islam, saya dinafikan kenaikan pangkat'. Kedua-dua bahagian B dan C diukur dengan menggunakan skala Likert 5 mata iaitu 1 - Sangat tidak setuju (STS), dan 5 - Sangat setuju (SS). Hasil kajian rintis menunjukkan kadar kebolehpercayaan yang tinggi iaitu nilai alfa Cronbach 0.91 dan 0.92 untuk bahagian B dan C.

Kesemua data yang telah diperolehi dianalisa dengan menggunakan perisian statistic IBM SPSS. Selain kaedah statistik deskriptif, pengkaji turut menjalankan analisis varians sehala (ANOVA) untuk menjawab objektif ketiga iaitu untuk mengenalpasti perbezaan tahap diskriminasi agama di antara majikan yang berlainan agama (Diez \& Barr, 2017; Pallant, 2011). Manakala kaedah ujian-t dijalankan bagi menjawab objektif kedua iaitu bagi mengenalpasti perbezaan tahap diskriminasi agama di antara pekerja lelaki dan wanita (Diez \& Barr, 2017; Pallant, 2011).

Secara keseluruhannya, majoriti responden yang beragama Islam adalah terdiri daripada lelaki (51.5\%), berumur di antara 21-25 tahun (64.4\%), berbangsa Melayu (95.5\%), belum berkahwin (81.8\%), mempunyai kelulusan SPM (43.2\%), berpendapatan bulanan di antara RM1,001 - RM1,500 (35.6\%), pengalaman kerja di antara 1 - 5 tahun (90.2\%), bekerja secara sepenuh masa (74.2\%), dan mempunyai majikan yang berbangsa Cina (54.5\%) dan Bergama Buddha (40.9\%). 


\subsection{DAPATAN KAJIAN}

Jadual 1 dibawah menghuraikan taburan kekerapan, peratusan dan min bagi bahagian B soal selidik iaitu amalan sebagai Muslim di tempat kerja. Berdasarkan nilai keseluruhan skor min dalam jadual 1 menunjukkan nilai 4.20 yang berada pada lingkungan (3.67 -5.00) iaitu tahap tinggi. Maka, kesimpulan yang boleh dibuat adalah majikan telah memberi layanan yang paling baik kepada para pekerja Islam untuk beribadah di tempat kerja. Namun demikian, didapati terdapat $18 \%$ majikan yang tidak membenarkan pekerja lelaki menunaikan solat Jumaat di masjid sedangkan itu merupakan kewajiban di dalam Islam. Selain itu, $16 \%$ daripada responden turut tidak bersetuju yang majikan mereka memberi masa yang cukup untuk menunaikan solat.

Jadual 1 Taburan kekerapan, peratusan dan min bagi amalan sebagai muslim di tempat kerja

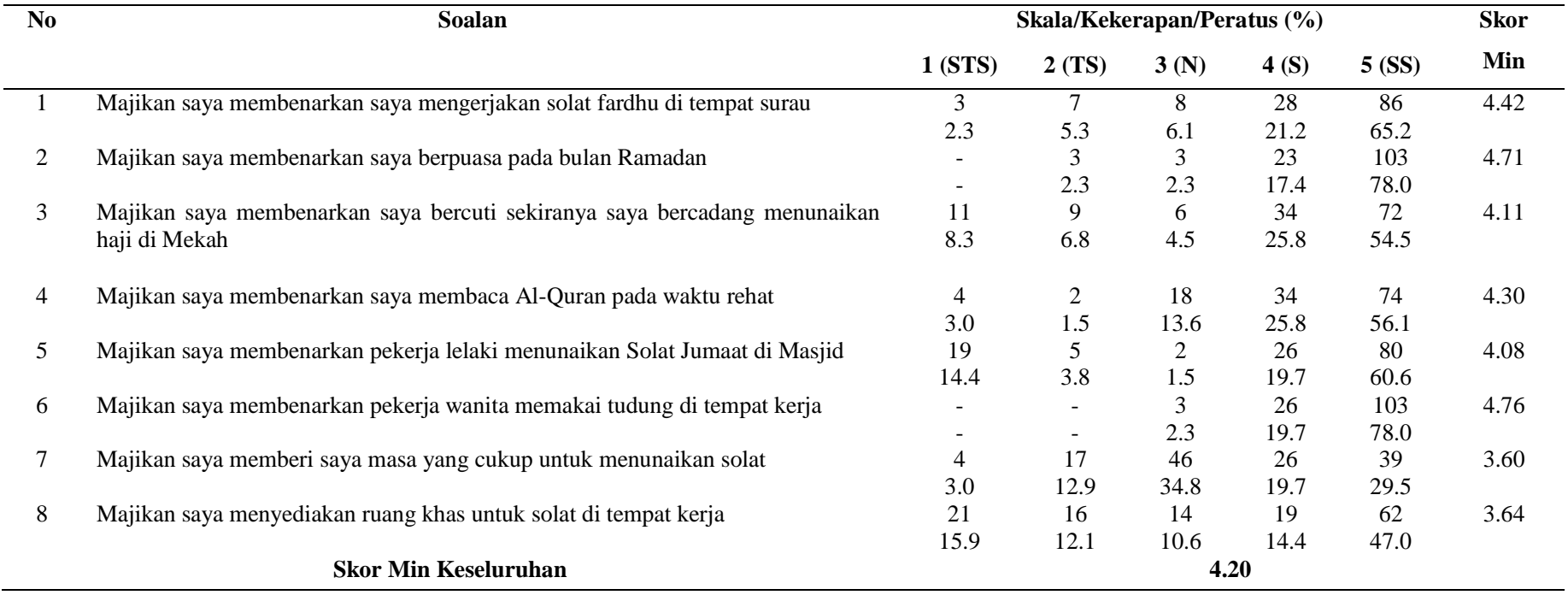

Jadual 2 Taburan Kekerapan, Peratusan dan Min bagi Bentuk Diskriminasi Terhadap Pekerja Islam di Tempat Kerja

\begin{tabular}{|c|c|c|c|c|c|c|c|}
\hline \multirow[t]{2}{*}{ No } & \multirow[t]{2}{*}{ Soalan } & \multicolumn{5}{|c|}{ Skala/Kekerapan/Peratus (\%) } & \multirow{2}{*}{$\begin{array}{l}\text { Skor } \\
\text { Min }\end{array}$} \\
\hline & & 1 (STS) & $2(\mathrm{TS})$ & $3(\mathrm{~N})$ & $4(S)$ & $5(\mathrm{SS})$ & \\
\hline 1 & Kerana saya beragama Islam, majikan saya melayan saya dengan teruk & $\begin{array}{c}97 \\
73.5\end{array}$ & $\begin{array}{c}22 \\
16.6\end{array}$ & $\begin{array}{c}5 \\
3.8\end{array}$ & $\begin{array}{c}5 \\
3.8\end{array}$ & $\begin{array}{c}3 \\
2.3\end{array}$ & 1.45 \\
\hline 3 & $\begin{array}{l}\text { Kerana saya beragama Islam, majikan saya menganggap saya sebagai pekerja } \\
\text { yang lemah }\end{array}$ & $\begin{array}{c}88 \\
66.7\end{array}$ & $\begin{array}{c}27 \\
20.5\end{array}$ & $\begin{array}{l}10 \\
7.6\end{array}$ & $\begin{array}{c}4 \\
3.0\end{array}$ & $\begin{array}{c}3 \\
2.3\end{array}$ & 1.54 \\
\hline 5 & $\begin{array}{l}\text { Kerana saya beragama Islam, majikan saya melayan saya dengan syak } \\
\text { wasangka }\end{array}$ & $\begin{array}{c}89 \\
67.4\end{array}$ & $\begin{array}{c}33 \\
25.0\end{array}$ & $\begin{array}{c}6 \\
4.51\end{array}$ & $\begin{array}{c}4 \\
3.0\end{array}$ & - & 1.43 \\
\hline 6 & $\begin{array}{l}\text { Kerana saya beragama Islam, majikan saya mengecualikan saya daripada } \\
\text { membuat keputusan }\end{array}$ & $\begin{array}{c}93 \\
70.5\end{array}$ & $\begin{array}{c}26 \\
19.7\end{array}$ & $\begin{array}{l}10 \\
7.6\end{array}$ & $\begin{array}{c}2 \\
1.5\end{array}$ & $\begin{array}{c}1 \\
0.8\end{array}$ & 1.42 \\
\hline 7 & $\begin{array}{l}\text { Kerana saya beragama Islam, majikan saya sering melakukan diskriminasi } \\
\text { terhadap saya }\end{array}$ & $\begin{array}{c}94 \\
71.2\end{array}$ & $\begin{array}{c}26 \\
19.7\end{array}$ & $\begin{array}{l}10 \\
7.6\end{array}$ & $\begin{array}{c}2 \\
1.5\end{array}$ & - & 1.39 \\
\hline 10 & $\begin{array}{l}\text { Kerana saya beragama Islam, saya menerima elaun yang lebih sedikit } \\
\text { berbanding pekerja bukan Islam }\end{array}$ & $\begin{array}{c}21 \\
15.9\end{array}$ & $\begin{array}{c}3 \\
2.3\end{array}$ & $\begin{array}{c}50 \\
37.9\end{array}$ & $\begin{array}{c}46 \\
34.8\end{array}$ & $\begin{array}{l}12 \\
9.1\end{array}$ & 3.19 \\
\hline 11 & $\begin{array}{l}\text { Kerana saya beragama Islam, saya diberikan cuti rehat yang lebih sedikit } \\
\text { berbanding pekerja bukan Islam }\end{array}$ & $\begin{array}{c}87 \\
65.9\end{array}$ & $\begin{array}{c}21 \\
15.9\end{array}$ & $\begin{array}{c}20 \\
15.2\end{array}$ & $\begin{array}{c}1 \\
0.8\end{array}$ & $\begin{array}{c}3 \\
2.3\end{array}$ & 1.58 \\
\hline 12 & Kerana saya beragama Islam, saya dinafikan kenaikan pangkat & $\begin{array}{c}83 \\
62.9\end{array}$ & $\begin{array}{c}31 \\
23.5\end{array}$ & $\begin{array}{c}7 \\
5.3\end{array}$ & $\begin{array}{c}5 \\
3.8\end{array}$ & $\begin{array}{c}6 \\
4.5\end{array}$ & 1.64 \\
\hline 13 & $\begin{array}{l}\text { Kerana saya beragama Islam, saya dinafikan untuk menjadi ketua di tempat } \\
\text { kerja }\end{array}$ & $\begin{array}{c}94 \\
71.2\end{array}$ & $\begin{array}{c}22 \\
16.7\end{array}$ & $\begin{array}{c}9 \\
6.8\end{array}$ & $\begin{array}{c}3 \\
2.3\end{array}$ & $\begin{array}{c}4 \\
3.0\end{array}$ & 1.49 \\
\hline 14 & $\begin{array}{l}\text { Kerana saya beragama Islam, saya dinafikan untuk mendapat "Anugerah } \\
\text { Pekerja Cemerlang" }\end{array}$ & $\begin{array}{c}95 \\
72.0\end{array}$ & $\begin{array}{c}19 \\
14.4\end{array}$ & $\begin{array}{c}8 \\
6.1\end{array}$ & $\begin{array}{c}6 \\
4.5\end{array}$ & $\begin{array}{c}4 \\
3.0\end{array}$ & 1.52 \\
\hline
\end{tabular}


15 Kerana saya beragama Islam, saya dinafikan daripada mendapatkan latihan di tempat kerja

16 Kerana saya beragama Islam, saya mendapat tugas yang lebih banyak berbanding pekerja bukan Islam

17 Majikan saya cenderung mengambil pekerja bukan Islam berbanding pekerja Islam

\begin{tabular}{cccccc}
91 & 24 & 10 & 6 & 1 & 1.50 \\
68.9 & 18.2 & 7.6 & 4.5 & 0.8 & \\
87 & 19 & 16 & 6 & 4 & 1.64 \\
65.9 & 14.4 & 12.1 & 4.5 & 3.0 & \\
1 & 39 & 17 & 50 & 25 & \\
0.8 & 29.5 & 12.9 & 37.9 & 18.9 & 3.45 \\
& \multicolumn{7}{c}{$\mathbf{1 . 7 9}$} \\
\hline
\end{tabular}

Skor Min Keseluruhan

Jadual 2 berikut menghuraikan taburan kekerapan, peratusan dan min bagi bahagian $\mathrm{C}$ soal selidik iaitu bentuk diskriminasi terhadap pekerja beragama Islam di tempat kerja. Berdasarkan nilai keseluruhan min skor dalam jadual 2, boleh disimpulkan bahawa tahap bentuk diskriminasi terhadap pekerja Islam berada pada tahap yang rendah (min skor $=1.79$ ). Namun demikian, dapatan kajian menunjukkan terdapat diskriminasi dari segi gaji di mana hampir 45\% menyatakan menerima gaji yang lebih rendah berbanding pekerja bukan Islam. Selain itu, 56\% responden turut menyatakan majikan mereka lebih cenderung untuk mengambil pekerja bukan Islam sebagai pekerja.

Secara keseluruhannya, daripada kedua-dua bahagian B dan C, dapat dirumuskan bahawa tahap diskriminasi majikan terhadap pekerja beragama Islam adalah di tahap yang rendah (rujuk Jadual 3). Namun demikian, seperti yang telah dinyatakan, pekerja beragama Islam mengalami diskriminasi dari segi pengambilan pekerja, gaji dan juga elaun, selain menghadapi kesukaran untuk menunaikan solat fardhu dan solat Jumaat.

Jadual 3 Tahap diskriminasi terhadap agama islam

\begin{tabular}{ccc}
\hline Skor Min & Sisihan Piawaian & Tahap \\
\hline 1.79 & 0.59 & Rendah \\
\hline
\end{tabular}

Jadual 4 di bawah menunjukkan perbezaan tahap diskriminasi agama di antara responden lelaki dan perempuan. Berdasarkan ujian-t, didapati bahawa terdapat perbezaan yang signifikan mengenai diskriminasi agama di antara jantina, $(\mathrm{t}=1.17, \mathrm{p}<0.05)$, di mana pekerja lelaki lebih mengalami diskriminasi berbanding pekerja wanita. Namun perbezaan di antara lelaki dan perempuan adalah minimal.

Jadual 4 Perbezaan Tahap Diskriminasi Terhadap Agama Islam antara Jantina

\begin{tabular}{|c|c|c|c|c|}
\hline Jantina & $\mathbf{N}$ & Skor Min & $\mathbf{t}$ & Sig. $P$ \\
\hline Lelaki & 68 & 1.87 & & \\
\hline Perempuan & 64 & 1.71 & 1.60 & 0.01 \\
\hline
\end{tabular}

Berikutnya, jadual 5 di bawah menunjukkan perbezaan tahap diskriminasi di antara majikan yang berlainan agama. Berdasarkan analisis varian (ANOVA) sehala, didapati bahawa terdapat perbezaan yang signifikan mengenai diskriminasi agama di antara majikan yang berlainan agama, $(\mathrm{F}=3.08, \mathrm{p}<0.05)$. Skor min yang paling tinggi ialah untuk majikan yang tidak mempunyai agama (Atheis). Faktor tidak mempercayai kewujudan Tuhan mungkin mempengaruhi tindakan mereka terhadap pekerja beragama Islam kerana beranggapan bahawa agama (dan ibadah) itu bukan suatu kewajiban.

Jadual 5 Perbezaan Tahap Diskriminasi Terhadap Agama Islam Majikan yang berlainan Agama

\begin{tabular}{lccc}
\hline Agama Majikan & N & Skor Min & Nilai F \\
\hline Islam & 52 & 1.68 \\
Buddha & 54 & 1.84 & 1.37 \\
Hindu & 4 & 1.91 & 3.05 \\
Kristian & 18 & 3.48 & \\
Atheis & 1 & 2.19 & \\
Tidak Diketahui & 3 & 0.01 \\
\hline
\end{tabular}

\subsection{PERBINCANGAN}

Secara keseluruhannya, dapatan kajian menunjukkan bahawa tahap diskriminasi agama dalam kalangan pekerja Islam berada di tahap yang rendah dengan nilai min sebanyak 1.79. Selain itu, terdapat perbezaan yang signifikan mengenai tahap diskriminasi agama antara jantina ( $\mathrm{t}$ $=1.17, \mathrm{p}<0.05)$. Bukan itu sahaja, analisa turut mendapati bahawa terdapat perbezaan yang signifikan antara tahap diskriminasi agama majikan yang berlainan agama $(\mathrm{F}=3.08, \mathrm{p}<0.05)$.

Hasil analisis dapatan kajian ini didapati berbeza dengan pengkaji sebelumnya. Sebagai contoh, Rafidah Hanim et al (2017) yang menyatakan bahawa diskriminasi agama di Malaysia berada pada tahap yang membimbangkan, dan Atirah Hasli, (2017) dan Rafidah 
Hanim, (2018) yang melaporkan bahawa pekerja Islam di Malaysia mengalami diskriminasi agama di tempat kerja. Ini mungkin disebabkan oleh faktor lokasi kajian yang dijalankan di negeri Johor, yang mempunyai sistem pentadbiran agama Islam yang berbeza berbanding negeri-negeri lain di Malaysia. Sebagai contoh, negeri Johor mempunyai Pelan Strategik Agama Islam Negeri Johor 2030 bagi tujuan untuk pembangunan ummah bagi menyuburkan agama Islam di negeri Johor (Firdaus Yon, 2018). Malah cuti mingguan negeri Johor juga telah ditukar daripada hari Sabtu dan Ahad ke Jumaat dan Sabtu bermula 1 Januari 2014. Perubahan ini secara tidak langsung menggambarkan kedudukan agama Islam di negeri Johor.

Selain itu, kajian ini juga dijalankan di pusat membeli belah dan bukannya di sektor perhotelan seperti dalam kajian Rafidah Hanim (2018). Justeru, diskriminasi agama khususnya berkaitan dengan larangan pemakaian tudung bagi pekerja perempuan beragama Islam tidak menjadi isu dalam kajian ini. Dapatan kajian ini, secara tidak langsung turut bercanggah dengan kajian oleh Ghumman dan Ryan, (2013) yang menyatakan bahawa majikan tidak membenarkan pekerja wanita untuk memakai tudung di tempat kerja. Namun begitu, perbezaan ini mungkin disebabkan oleh lokasi kajian Equal Employment Opportunity Commission, iaitu di negara minoriti Islam. Justeru dapatan kajian ini adalah penting kerana ia membuktikan bahawa hasil kajian lepas tidak boleh digeneralisasikan. Lebih banyak kajian juga perlu dilakukan bagi mengetahui sejauh mana pekerja beragama Islam yang bekerja di sektor lain mengalami diskriminasi agama khususnya di tempat kerja.

Akhir sekali, kajian ini turut membuktikan bahawa majikan yang tidak beragama cenderung untuk mengamalkan diskriminasi terhadap pekerja beragama Islam. Antara bentuk diskriminasi yang dikenalpasti ialah dari segi pengambilan pekerja, pembayaran gaji dan elaun yang lebih rendah berbanding pekerja bukan beragama Islam. Hasil kajian ini adalah disokong oleh Panahi (2017) yang menyatakan bahawa majikan bukan Islam lebih cenderung untuk mengambil pekerja bukan Islam bekerja berbanding pekerja Islam. Selain itu, ia turut disokong oleh Rahmah, Zulkifly Osman, Syazwani, (2013) yang mendapati bahawa pekerja beragama Islam menerima gaji dan elaun yang lebih rendah berbanding pekerja bukan Islam.

Terdapat beberapa faktor yang mungkin menyumbang kepada perbezaan ini. Yang pertama ialah kecenderungan seseorang untuk berpihak kepada individu daripada latar belakang yang sama. Ini dibuktikan oleh Panahi (2017) yang mendapati bahawa kecenderungan tersebut bukan hanya didapati berlaku dalam kalangan pengurus bukan Islam tetapi juga berlaku dalam kalangan pengurus beragama Islam. Dalam erti kata lain, majikan lebih cenderung untuk memilih pekerja yang mempunyai pegangan agama yang serupa. Faktor kesamaan ini didapati bukan hanya mempengaruhi agihan gaji dan elaun tetapi juga amalan sumber manusia yang lain seperti proses pengambilan pekerja. Faktor kedua yang mungkin mendorong majikan bukan Islam untuk memberi gaji dan elaun yang lebih rendah berbanding kepada pekerja bukan Islam ialah persepsi negatif disebabkan oleh stereotaip dan prejudis kepada agama Islam dan penganutnya. Tragedi 11 September 2001 misalnya telah melonjakkan sentimen Islamofobia di seluruh dunia dan Malaysia tidak terkecuali. Faktor ini adalah selari dengan Jasperse et al (2012), Rabasa et al, (2004) dan (Kaushal, Kaestner dan Reimers, 2007).

\subsection{KESIMPULAN}

Kesimpulannya, kajian ini telah berjaya menjawab semua objektif kajian yang telah dinyatakan iaitu untuk mengenalpasti tahap diskrimasi agama, perbezaan tahap diskriminasi agama antara jantina, dan perbezaan tahap diskriminasi agama antara majikan berlainan agama. Walaupun tahap diskriminasi agama adalah rendah, namun terdapat beberapa aspek yang perlu diberi perhatian seperti peruntukkan waktu untuk solat fardhu, dan kebenaran untuk pekerja lelaki mengerjakan solat Jumaat. Pihak majikan yang bukan beragama Islam sewajarnya merujuk Garis Panduan Menunaikan Solat Dalam Waktu Kerja yang telah dikeluarkan oleh Jabatan Tenaga Kerja Semenanjung Malaysia (2019) bagi memastikan pekerja beragama Islam dapat menunaikan tanggungjawab mereka sebagai seorang Muslim. Garis panduan tersebut mencadangkan agar majikan memberikan pelepasan kepada pekerja sekurang kurangnya 20 minit bagi solat fardhu dan 1 jam 30 minit bagi solat Jumaat. Selain itu, pihak majikan juga sewajarnya tidak menjadikan faktor agama sebagai indikator penetapan pengambilan pekerja, dan penetapan gaji serta elaun. Sebaliknya, setiap pekerja atau calon pekerja sewajarnya dinilai secara objektif dan dengan merit iaitu dengan melihat kepada kemahiran, pengetahuan, dan pengalaman mereka.

Namun, kajian ini dibatasi oleh beberapa limitasi kajian. Antaranya ialah, dapatan kajian hanya berdasarkan kepada empat buah kompleks membeli belah yang dikaji, justeru itu ia tidak menggambarkan amalan diskriminasi di seluruh kompleks membeli belah samada di negeri Johor mahupun di seluruh Malaysia. Selain itu, dapatan kajian ini yang menunjukkan tahap diskriminasi agama yang rendah adalah bertentangan dengan beberapa kajian lepas, sebagai contoh, Rafidah Hanim et al (2017). Ini kerana kajian beliau memfokus kepada responden wanita sepenuhnya berbanding kajian ini yang didominasi oleh responden lelaki (51.5\%). Memandangkan perbezaan skop kajian ini dengan kajian lepas, dan jumlah kajian yang terhad berkaitan disriminasi agama, khususnya dalam kalangan pekerja beragama Islam (semua bangsa), maka pengkaji mencadangkan agar lebih banyak kajian berkaitan diskriminasi agama dijalankan di sektor dan negeri lain. Data diskriminasi agama perlu dikumpul bagi membolehkan pihak kerajaan, khususnya Kementeria Sumber Manusia, melalui Jabatan Tenaga Kerja merangka garis panduan yang berkaitan sebagai rujukan kepada para majikan di Malaysia, tidak kira yang beragama Islam mahupun yang bukan. Sebagai penutup, kajian yang telah dijalankan ini telah menyumbang kepada bidang ilmu pengurusan sumber manusia, khususnya tentang amalan diskriminasi agama oleh majikan terhadap pekerja beragama Islam.

\section{Rujukan}

Ahluwalia, M. K., \& Pellettiere, L. (2010). Sikh Men Post-9/11: Misidentification, Discrimination, and Coping. Asian American Journal of Psychology. Psychological Association 1(4), 303-314

Atirah Hasli, (2017). Cadangan Akta Khas Diskriminasi Perlu Dilihat Positif. Sinar Harian. http://www.sinarharian.com.my/nasional/cadangan-akta-khas-diskriminasiperlu-dilihat-positif-1.758367

Cheung, H. K., King, E., Lindsey, A., Membere, A., Markell, H., \& Kilcullen, M (2016). Understanding and Reducing Workplace Discrimination.

Coglievina, S., Hutchinson, T., \& Van Emden, G. (2007). Religious Discrimination and Legal Protection in the European Union.

Equal Employment Opportunity Commission, (2008). EEOC Compliance Manual. Religious Discrimination. Retrieved from 4 Mei 2018, https://www.eeoc.gov/policy/docs/religion.html

Farhanah Abd. Malek. (2017). 7 hotel antarabangsa disiasat. Isu larangan bertudung terhadap pekerja beragama Islam. Utusan Malaysia. 
http://www.utusan.com.my/berita/nasional/7-hotel-antarabangsa-disiasat-1.560114

Firdaus Yon. (2018). Pemerkasaan syiar Islam di Johor. Sinar Harian, https://www.sinarharian.com.my/article/1352/EDISI/Johor/Pemerkasaan-syiar-Islam-di-Johor

Gabbidon, J., Farrelly, S., Hatch, S. L., Henderson, C., Williams, P., Bhugra, D., Dockery, L., Lassman, F., Thornicroft, G., \& Clement, S. (2014). Discrimination Attributed to Mental Illness or Race-Ethnicity by Users of Community Psychiatric Services. 9290-0

Goodstein, L., \& Lewin, T. (2001). Victims Of Mistaken Identity, Sikhs Pay A Price For Turbans. New York Times,

Ghumman, S., Ryan, A. M., Barclay, L. A., \& Markel. K. S. (2013). Religious Discrimination in the Workplace: A Review and Examination of Current and Future Trends. J Bus Psychol (2013) 28:439-454 DOI 10.1007/s10869-013-9290-0

Isaiah, O.D., Ojiabo, U., \& Alagah, A. D. (2017). Workplace Discrimination and Employee Performance in Nigerian Food and Beverage Sector. International Journal of Advanced Academic Research | Social \& Management Sciences | ISSN: 2488-9849 3(11), 61-85

Jang, Y., Chiriboga, D. A., \& Small, B. J. (2008). Perceived Discrimination and Psychological Well-Being: The Mediating and Moderating Role of Sense of Control. The International Journal of Aging and Human Development, 66(3), 213-227.

Janson, E. (2011). Stereotypes That Define "Us": The Case of Muslim Women. ENDC Proceedings, 14, 181-196

Jasperse, M. L., Ward, C., \& Jose, P. E. (2012). Identity, Perceived Religious Discrimination, and Psychological Well- Being in Muslim Immigrant Women. Applied Psychology: An International Review, 61 (2), 250-271 Doi: 10.1111/J.1464-0597.2011. 00467

Jones, K. P., Arena, D. F., Nittrouer, C. L., Alonso, N. M., \& Lindsey, A. P. (2017). Subtle Discrimination in the Workplace: A Vicious Cycle. Industrial and Organizational Psychology/page 1 of 26/March 2017

King, E. B., \& Cortina, J. M. (2010). The social and economic imperative of lesbian, gay, bisexual, and transgendered supportive organizational policies. Industrial and Organizational Psychology: Perspectives on Science and Practice, 3, 69-78.

Kwaku, C. A., Addae, C., Nkansah, J., Appiah, F. N. (2013). Workplace Discrimination and Its Impact on Employee Performance

Marafuga, A., Dona, T. D., Paradas, J., Cortes, A. E., \& Perera, M. (2017). Employee Perceptions in the Workplace: Discrimination, Work Motivation, Teamwork/Citizenship, and Locus of Control. International Journal of Scientific and Research Publications, 7(12), 716 ISSN 2250-3153

Mays, A. J., (2017). A Narrowing Space: Violence And Discrimination Against India's Religious Minorities. ISBN 978-1-907919-90-9. Published June 2017.

McMahon, B. T., \& Shaw, L. R. (2005). Workplace Discrimination and Disability. Journal of Vocational Rehabilitation 23, $137-143$.

Mohd Nor Aizat Othman. (2012). Diskriminasi dalam Pasaran Buruh: Kajian Kes di Sektor Swasta. Prosiding Perkem, Vii( 2), 922 - 932 Issn: 2231 - $962 x$.

Nienartowicz, J. M. (2014). Direct and Indirect Discrimination in European Union Law. How to Draw a Dividing Line? International Journal of Social Sciences, III(1), 41-55

Norhawa Mohd. Ali. (2018). Diskriminasi wanita bertudung. Utusan Malaysia http://www.utusan.com.my/berita/nasional/diskriminasi-wanita-bertudung-1.589965

Pallant, J. (2011). SPSS Survival Manual: A Step By Step Guide To Data Analysis Using The SPSS Program 4th Edition. Retrieved from www.allenandunwin.com/spss

Panahi, O.P. (2017). When Workplace Diversity Backfires: Perceived Discrimination against Employees in the Malaysian Workplace.

Parkins, I. S., Fishbein, H. D., \& Ritchey, P. N. (2006). The Influence of Personality on Workplace Bullying and Discrimination. Journal of Applied Social Psychology, 36(10, pp. 2554-2577

Pavalko, E. K., Mossakowski, K. N., \& Hamilton, V.J. (2003). Does perceived discrimination affect health? Longitudinal relationships between work discrimination and women's physical and emotional health. Journal of Health and Social Behavior, 43 (March), 18-33

Pekeliling Am Kerajaan Johor Bilangan 3 Tahun 2013. Cuti Mingguan Negeri Johor

Rabasa, A.M., Benard, C., Chalk, P., Fair. C., Karasik, T., Lal, R., Lesser, I., \& Thaler, D. (2004). The Muslim World After 9/11. Library of Congress Cataloging-inPublication Data. DS35.74. U6M875 2004 327.73017'67'090511-dc22

Rafidah Hanim. (2018). Menangani gangguan seksual, diskriminasi agama. Utusan Malaysia. http://www.utusan.com.my/rencana/utama/menangani-gangguanseksual-diskriminasi-agama-1.670539

Rafidah Hanim, Azizi Ayob, Fadzillah Zulkifli, Amira Ismail, \& Hazrin Chong. (2017). Amalan Diskriminasi dan Gangguan Seksual Di Kalangan Wanita Bekerja Di Malaysia, Retrieved from 4 Mei 2018, http://wafiq.my/2018/04/02/menangani-masalah-diskriminasi-agama-gangguan-seksual-di-kalangan-wanita-di-tempatkerja-macsa/i

Rahmah Ismail, Zulkifly Osman, \& Syazwani Malek. (2013). Perbezaan Upah Mengikut Jantina dan Diskriminasi Majikan dalam Sektor Teknologi Maklumat dan Komunikasi. Jurnal Teknologi (Social Sciences), 63(1), 41-50.

Schafgans, M.A. (1998). Ethnic Wage Differences in Malaysia: Parametric and Semiparametric Estimation of the Chinese-Malay Wage Gap. Journal of Applied Econometrics, 13(5), 481-504.

Shahrul Mizan Ismail, \& Aini Afiqah Marzidin. (2017). Pemakaian Serban Di Sisi Penganut Islam Dan Sikh Di Malaysia: Wujudkah Diskriminasi?

Smith, E.R., \& Mackie, D.M. (2002) Social Psychology 3rd Edition. Budapest, Osiris Publishing House

Valfort, M.A. (2015). Religious discrimination in access to employment: a reality Antisemitism and Islamophobia on the French labour market. Policy Paper, 1-143. Paris: Institut Montaigne., ISSN 1771-6756

Williams, D. R., John, D. A., Oyserman, D., Sonnega, J., \& Mohammad, S. A. (2012). Research on discrimination and health: An exploratory study of unresolved conceptual and measurement issues. American Journal of Public Health, 102(5), 975-978

Winnie Simun, \& Azizan Morshidi. (2016). Diskriminasi Wanita Dalam Sektor Pekerjaan. DOI: 10.13140/RG.2.2.32227.55848

Tesfaye, Y. (2010). The Effect of Discrimination on Job Performance and Job Satisfaction. (Bachelor dissertation, Wolverhampton University, https://www.theseus.fi/handle/10024/38525

Turner, M. J. (2014). Discrimination in the Workplace: Authenticity and the Genuine Occupational Qualification Exception.

Zaiton Othman, \& Nooraini Othman. (2015). A Literatural Review on Work Discrimination among Women Employees. Asian Social Science; 11(4); 26-32. ISSN 1911-2017 E-ISSN 1911-2025 